\title{
The Effect of Asymmetry on Vertical Dynamic Response of Railway Vehicles
}

Fillemon Nangolo, Josef Soukup

Faculty of Production Technology and Management, J. E. Purkyne University in Usti nad Labem. Pasteurova 3334/7, 400 01 Usti nad Labem. Czech Republic. E-mail: nangolo@fvtm.ujep.cz, soukupj@fvtm.ujep.cz

An experimental and analytical study on the effect of asymmetry on vertical dynamic response of railway vehicles has been conducted. The experimental study featured a typical vehicle model of laboratory scale and a real railway vehicle wagon. The experiment was used to gain insight into the effect of asymmetry on vertical dynamic response and to validate an analytical model of the vehicle-track interaction. This paper presents the results from the study and shows that mechanical asymmetry changes the behaviors of the system. The current contribution introduces a methodology of analytical solution of vertical dynamic response of the railway vehicle. Moreover, a mathematical model according to the physical system considered was developed under MATLAB environment.

Keywords: vehicle asymmetry, railway vehicle, analytical model, experiment test

\section{Acknowledgement}

The research work is supported by the Student Grant Agency (SGA) - UJEP, Czech Republic.

\section{References}

[1] SOUKUP, J., VOLEK, J. a kol.: Kmitání mechanických soustav-vozidel. Analýza vlivu nesymetrie. Acta Universitatis Purkynianae, Universita J. E. Purkyně in Ústí nad Labem, 2008, ISBN 978-80-7414- 020-4

[2] JIMIN, H., ZHI-FANG, F: Modal Analysis. 2001. ISBN 0750650796.

[3] GERLICI, J., LACK, T.: Modified HHT Method for Vehicle Vibration Analysis in Time Domain Utilisation. Page 10. Applied Mechanics and Materials, Scientific. Net, Switzerland. V tisku (ISSN 1662-7482)

[4] MEIROVITCH, L.: Analytical Methods in Vibration. College of Engineering Sciences, Arizona State University. 1967.

[5] NANGOLO, N., SOUKUP, J.: Modeling of Vertical Dynamic Response of Railway Vehicle System with Experimental Validation. Machine Modeling and Simulation. 2012, Poland.

[6] BLUDELl, M., HARTY, D.: The Multibody Systems Approach to Vehicle Dynamics. Elsevier, 2004, ISBN 0750651121.

[7] ERIK, M. L.: Development of an Intermediate DOF Vehicle. North Karolina State University, 1998.

[8] DANIEL, J. I.: Engineering Vibration II, Virginal Polytechnic Institute and State University, New Persey. 2001. ISBN: 013-0174483.

[9] SUN, Y. Q., DHANASEKAR, M., ROACH, D.: A Three-Dimensional Model for the Lateral and Vertical

Dynamics of Wagon-Track System. Proceedings of the institution of Mechanical Engineers.

[10] SVOBODA, M., SOUKUP, J.: Dynamic Measurment of Four-Axle Railway wagon. Manufactoring Technology, vol.13 (2013), no. 4, p. 552-558. ISSN 1213-2489

[11] SVOBODA, M., SOUKUP, J.: Verification of Numeric Solution by Experiment for Examination Vertical Oscillation of a Mechanical System. Manufactoring Technology, vol.13 (2013), no. 4, p. 559-563. ISSN 1213-2489

[12] SEGLA, Š., OREČNÝ, M., TRIŠOVIČ, N.: Pasive Seat Suspension With a Vibration Absorber. Manufactoring Technology, vol.13 (2013), no. 4, p. 530-539. ISSN 1213-2489 